\title{
Strategic alliances: A concept for global and national marketing
}

\author{
Joseph A. Montgomery, Ec.D.
}

This paper explores the steps countries around the world have taken to assist their manufacturing and service sectors to set up profitable strategic alliances based on their own needs and nationalistic traits. It also examines programs undertaken in Canada at the federal, provincial and local level to nurture strategic alliancing as the stepping stone to global, national and local marketing in the 1990's and into the upcoming millennium. Using a combination of primary and secondary data, the author provides an unbiased appraisal of Canada's efforts in the field of strategic alliancing. The paper concludes with recommendations to form strategic alliances between the national, provincial, regional, municipal governments, by working in close cooperation with industrial associations, specific industrial sectors, universities and the service sector.

Keywords: strategic alliance, manufacturing, service sector, clusters, networks

"Technology and globalization are transforming economic activity. Governments cannot change this. Nations cannot hide from it. What we can do and are doing is work to ensure that Canada and Canadians are winners in this new global economy. An economy which above all focuses on knowledge and our knowledge capacity. That means helping our universities modernize and enhance their science capacity. It means helping our teaching hospitals improve their research capacity. It means increasing our investments in new technologies, research and development."

Prime Minister Jean Chretien, February 13, 1997, Budget, 1997

\section{Introduction}

Strategic alliancing is not new. The concept has been in use since the beginning of recorded time. In Europe, as an example, the Romans utilized intermarriages as strategic alliances to consolidate newly conquered territory.

In North America, one of the best-known strategic alliances was the Iroquois Nation which included six Indian tribes, the Cayugas, Mohawks, Oneidas, Onondagas, Senecas and Tuscaroras. Between them, they controlled territory stretching from the St. Lawrence River, north to Lake Huron, and southward through New York State reaching parts of Pennsylvania, Ohio and Michigan (Webster's Encyclopedic Dictionary, Column 2266). 
Today, strategic alliances have become buzz words loosely used but not necessarily understood in the true context of the meaning. There have been many definitions of what constitutes a "strategic alliance" but one definition that has stood the test of time with sufficient flexibility to suit most situations is from Jordan Lewis's book, Partnerships for Profit:

"A strategic alliance is a formal and mutually agreed commercial collaboration between companies. The partners pool, exchange or integrate specific business resources for mutual gain. Yet the partners remain separate businesses."

However, in the Marcar Management Institute's Managing and Growing Strategic Alliances, Report \#821, Spring 1993, the terms of reference are widened as follows:

"An alliance is any relationship a major business unit forms to meet a critical need without a merger. Organizations cooperate in an alliance, sharing risks and benefits to reach a common goal. Informal alliances operate without binding agreements: the partners maintain individual control. Formal alliances are more complex, presenting more risks and issues of control, and equity alliances involve even stronger controls and common ownership of the alliance, which may be a separate entity."

Today, if a separate business entity is established where it is jointly owned by two or more businesses with the percentage of ownership depending on the amount of equity financing by the parties, it would not be considered a strategic alliance but rather a joint venture.

And as one delves deeper into this fascinating subject, it becomes obvious that there is an interchange of definitions which tends to cloud basic issues and makes analysis difficult if not impossible. Also, various countries throughout the world have developed strategic alliance programs based on their own national needs of the manufacturing and service sectors.

In the following pages where excerpts from other studies are replicated, terminology is as used in the original text. However, as it applies to this paper, the comments and terminology are based on the following definitions of a strategic alliance, a network, a flexible manufacturing network and manufacturing clusters.

\section{A strategic alliance (SA)}

The definition of a strategic alliance is elusive and yet there are certain factors that are common in most definitions appearing in papers written by Economic Development Practitioners and Economists specializing in alliancing and networking. 
Some of the commonalities are listed below. However, because strategic alliances are between parties and are designed to provide a win-win situation for all participants, they can be very specific, very general or anywhere in between.

1. Sharing of risks and benefits.

2. All parties have a common goal.

3. Ownership of companies do not change.

4. Individual firms concentrate on core strengths.

5. Clear definition of roles and responsibilities.

6. Good personal relations through TRUST.

7. With or without an agreement.

8. The working partners remain in control.

The reason for establishing strategic alliances are as broad as the business spectrum today. As an example, accelerating R \& D and cost-sharing are two commonly mentioned reasons for establishing a strategic alliance but if the firms in question aren't involved in R \& D, then these factors have no relevance.

\section{Network}

There are a proliferation of networks ranging from flexible manufacturing networks (FMN's), business networks, social networks and associations that operate networks within their membership.

For the purpose of this paper, the major difference between a strategic alliance and a network is that within a network, no manufacturing takes place. Bulk purchasing, discounts at hotels, car rentals, etc., sector training, R \& D consortiums are some operations that would be considered to be networks. In Ontario, a number of manufacturers of mining equipment have banded together in a network for the purpose of merchandising their combined product lines around the world.

P. Roy, CMC (1995) provides the following definition of a business network:

"The participating firms undertake projects-in-common in order to improve their competitiveness in domestic and global markets, distinguishing business networks from all other forms of networks and networking."

\section{Flexible manufacturing network}

Flexible manufacturing networks are similar to strategic alliances in many ways. However, strategic alliances can be complex and designed to be long term whereas FMN's are usually 
short-term, formed for a very specific reason (development of a new product, penetration of a new market, designed to satisfy a "niche" market), and once the base purpose has been fulfilled, the FMN is disbanded.

P. Blais in an article written in May, 1944 states:

"A production network might be comprised of a venture capitalist, a university research department, a product design company, many parts suppliers, an assembly company, an advertising firm, a packaging company and an accounting firm. An important source of flexibility, therefore lies outside the firm, in the diverse array of businesses, organizations and high-order institutions available for the formation of strategic alliances."

One of the best definitions of a FMN is contained in a paper published by the Appalachian Centre for Economic Networks, "Creating Flexible Manufacturing Networks in North America", 1991.

"Flexible manufacturing networks are best understood as a set of processes for continually generating and then disbanding, as appropriate-constellations of resources such as those observed in the European examples. Once FMN's are viewed as a class of highly adaptive processes, the role of information technology becomes clear as an enabler and facilitator of these processes' close fit with the changing environment."

In Italy, many SME's are participating in multiple FMN's at the same time. Products can be complementary but not competitive.

\section{Manufacturing clusters}

In many cases, manufacturing clusters evolved to take advantage of special natural resources, specialized people skills, availability to markets and, in some cases, proximity to centres of learning. Well-developed infrastructure was necessary as the clusters grew but was sometimes developed concurrently with the clusters and wasn't a prerequisite for the initial development.

Volume 1, "Building Technology Bridges" by KPMG, June, 1966 states:

"A cluster is an agglomeration of key industries, supporting sectors and economic infrastructure that are interdependent because they share technology or skills and use similar inputs, such as suppliers. The defining characteristic of a cluster is high connectivity. Within the cluster, firms form strategic alliances with 
suppliers and even competitors. They also draw on a common labour pool which serves to diffuse new knowledge and skills rapidly throughout the cluster."

Some of the better known clusters include the Silicon Valley, California (computer chips), Boston, Massachusetts (high technology), Ottawa, Ontario (high technology), Hamilton, Ontario (iron and steel). When the Big Three automakers introduced the Just In Time (JIT) parts delivery program, areas around major auto plants received an influx of auto part manufacturers resulting in mini-clusters such as Durham Region, Windsor and the area around Oakville, Ontario. Elkhart, Indiana, U.S.A., noted as a house trailer manufacturing cluster is a centre of specialist firms (axle assemblies, trailer skins, kitchen units, etc.) who concentrate on making custom components on a contractual basis for many assemblers of trailers.

One of the major purposes of this study is not to explore what makes a strategic alliance work but rather what steps have different countries undertaken to assist their manufacturing and service sectors to set up profitable strategic alliances based on their own needs and nationalistic traits.

The second major thrust is to examine programs undertaken in Canada at the federal, provincial and local level to nurture strategic alliancing as the stepping stone to global, national and local marketing in the 1990's and into the upcoming millennium.

As a practicing Economic Development Officer for twenty-seven years, first at the municipal level and then representing a region plus ten years consulting services, especially in the field of strategic alliances, some of the data will be from my personal files plus excerpts from other studies undertaken by various individuals and groups.

Finally, the paper presents an unbiased appraisal of Canada's efforts in the field of strategic alliancing. Furthermore, consideration is given to possible courses of action that could be undertaken at various political levels to assist the nation's manufacturing and service firms through a strategic alliance undertaking. In certain instances, it will be necessary to discuss some of the aspects of a successful strategic alliance without developing detailed case studies.

\section{The Danish network program}

The dramatic economic results of Denmark's Network Program has been fully documented by many groups including Canada's Embassy Staff Member John N. Grantham, with the result that certain portions of Canada's own program initiated in 1996 closely resembles the Danish model.

Denmark is a small country (16,576 square miles) with a population of approximately 5 million, a manufacturing sector of small and medium sized operations (only 5 major firms) and before 
the establishment of their unique and highly successful network program deeply in debt (\$U.S. 50 billion).

Since 1989 when the networking program was established, Denmark changed its lack-lustre performance in manufacturing and exporting into a world leader, second only to Japan. While their program was called networking, there were many instances where the format utilized by the manufacturing firms was in actuality a strategic alliance rather than a network.

\section{The Danish program}

The original concept was conceived by an American, Mr Richard Hatch, who worked through a business contract with Denmark. The program that was finally adopted in 1989 was fine-tuned by Danish officials. The definition of a network was the basis for their many faceted program that proved so successful. The following excerpt is taken from a comprehensive report filed by John N. Grantham, Commercial Counsellor, Canadian Embassy, Copenhagen, 31 March, 1992 addressed to Mr. A. T. Eyton, Associate Deputy Minister, Productivity Secretariat, Industry, Science, Technology Canada, Ottawa on 1 April, 1992:

In the Danish Program, Networks are defined in fairly precise terms:

a) Network cooperation is concrete, prolonged, contractually binding cooperation between a group of companies;

b) Their cooperation includes joint establishment, development and operation of one or more activities which companies cannot manage alone; and

c) Through cooperation companies will be able to solve bigger and more complicated tasks. The form of network cooperation intended by the program may be a means for SME's to achieve economies of scale, while at the same time preserving their independence.

\section{Conditions and funding}

The Industry Network Program was scheduled to run for three years (August 1989 to 1992) based on a total funding of $\$ 30$ million Canadian.

Some of the major segments of the program and allotted funding are listed below:

1) Creating the Basis was primarily a public relations program, $\$ 4$ million Canadian funding and designed to:

a) provide information and awareness program; 
b) train highly experienced industry advisers as Scouts and Brokers;

c) research perform analysis (sectoral studies), develop a standard network and identify tax constraints.

2) Feasibility Studies and Planning with funding of $\$ 6$ million Canadian, provided support for:

a) up to $\$ 15,000$ Canadian for feasibility studies;

b) up to 50 per cent of planning costs for positive feasibility studies;

c) groups of three or more firms; areas of cooperation including:

i) joint technology development;

ii) joint utilization of production facilities;

iii) joint market and technology monitoring;

iv) joint marketing;

v) other strategically important activities.

3) Establishment and Early Cooperation with funding of $\$ 20$ million Canadian:

On approval of a feasibility study to establish a network, an application for a grant toward the establishment and operation of the network up to:

1. 50 per cent of the expenses during the first year;

2. 30 per cent of the expenses during the second year.

Only common costs related to the network could be claimed and these costs will only be paid to one company, not the broker.

\section{Export networks}

Effective October, 1991 to 1993 with a total funding of \$22 million Canadian.

In phase one, the structuring phase, support was available in the form of costs associated with determining the feasibility of the network and the necessary planning involved.

In phase two, the introduction phase, a grant of up to 50 per cent was available.

Repayment was required over a 5 year period if the network was successful.

\section{Tourism networks}

Effective August, 1991 to December, 1993 with funding of \$12 million Canadian. 
In phase one, support was available to cover 75 per cent of the cost, up to $\$ 20,000$ Canadian, of a feasibility study.

In phase two, the framework plans and budget agreements were entitled to support up to 50 per cent, maximum $\$ 10,000$ Canadian.

In phase three, the operations phase, grants were available to cover 50 per cent of the cost of establishing a tourism network in the first year and 30 per cent in the second year.

The networks could be vertical (all of the same type of operation) or horizontal (covering a myriad of tourism type operations).

\section{Scouts and brokers}

The key to the success of the entire program was the recruitment and training of highly experienced and motivated persons to be trained as network scouts and brokers.

\section{Scouts}

The basic function of scouts was to identify SME's interested in networking. The training program involved two, three-day sessions separated to coincide with the broker training program.

\section{Brokers}

The purpose of brokers was to sell networking to SME's.

They acted as a right-hand person, mentoring the network and invoicing for their services on a regular basis.

They established detailed roles, joint functions, benchmarks and kept the network on track.

Training consisted of four seminars, the first for three days while the other three ran for two days with a time separation between seminars for developing a case study with the scouts.

Brokers were selected from among bankers, accountants, lawyers and private consultants who had considerable SME experience.

Results of networks (Phase 2, Feasibility/Planning)

Total networks investigated 
Replies to questionnaire

Number already formalized

2249 per cent

Number on track

1022 per cent

Number not formalized

1329 per cent

Lost interest and doubtful

13

\section{Positive results}

Markets strengthened

64 per cent

New product development

47 per cent

Reorganization

33 per cent

Better operation

Average increase in sales

22 per cent

04 per cent

\section{Inhibiting factors}

Lacked resources

Long preparatory time

Different opinions among network members

Differences In resources among network

44 per cent

38 per cent

24 per cent

29 per cent

\section{Results of networks (Phase 3, establishment)}

Total questionnaires sent out

Answered

Marketing new/existing products

Changed product development

New production facilities/equipment

Increased sales

Reduced cost of existing products

\section{Examining the results}

Total funding

Companies in networks

Types of Networks

Firms with less than 20 employees

Five major manufacturing/service sectors:

Metal Working

Wood \& Furniture

Construction
100

82

50 per cent

39 per cent

13 per cent

93 per cent

15 per cent

$\$ 30$ million Canadian

3,000

03

53 per cent

23 per cent

14 per cent

09 per cent 
Food Products

Electronics
09 per cent

09 per cent

\section{Cooperation among industries in the Valencian community, Spain}

\section{Impiva network program}

The Norwegian and Danish models represented national approaches whereas, the Valencian was regional in scope and involved three major communities plus seventeen smaller municipalities.

The fast-approaching advent of the European Common Market in January, 1993 with its increased competition in many of the major industrial sectors important to the Valencia area forced an evaluation of the area's manufacturing sectors in 1990. It was found that:

- 85 per cent of firms had less than 20 employees;

- the average size company had 11.6 employees;

- major export products were footwear, toys and textiles;

- many firms were family operations in the area of management operations.

The establishment of the "Impiva Network Program" was closely based on the Danish model but down-sized to fit a regional area program. The definition of a network appears on page four of a report written by S.H. Peinado, Network Programme Director of Impiva:

\footnotetext{
"Networks permit small and medium-sized companies to successfully compete with the large firms by obtaining a larger operative scale and a greater capacity for action, while at the same time, maintaining the characteristic advantages of the small firms: independence, flexibility, dynamism and adaptability to rapid change."
}

Three courses of action were identified as being major assets for a network member firm:

- common solutions to common problems/access to high cost resources;

- development of complementarity among the firms;

- development of quality and subcontracting conditions.

\section{Development of training program for mentors/ brokers}

In 1990/91, a training course for 75 specialists to act as advisors and consultants was undertaken based on the Danish model. Although they were independent, close liaison was maintained with Impiva officials for the proper allocation of financial incentives. 
The training course involved four, two-day seminars with fifteen days between courses for practical field training.

The curriculum was designed to provide essential training for brokers to be able to handle:

1. the identification of interests and actions to be developed jointly;

2. the identification and/or recruitment of appropriate partners for the project;

3. the study and analysis of how to best achieve agreements among firms and partners;

4. the establishment of agreements, internal rules and regulations;

5. the provision of advice during the establishment and development of networks;

6. the collaboration with partners and other Impiva advisors for external solutions;

7. the development of feasibility studies;

8. the setting of benchmarks and acting as a catalyst.

\section{Background of brokers}

During 1991/92, there were two courses for brokers. The following is a breakdown of their academic and professional backgrounds:

$\begin{array}{ll}\text { Economists } & 31 \\ \text { Engineers } & 06 \\ \text { Technical Engineers } & 08 \\ \text { Psychologists } & 03 \\ \text { Lawyers } & 08 \\ \text { Others } & 20\end{array}$

\section{Background of network promoters}

This is the only reported program that developed a specific program for network promoters. Below is the distribution of network promoters:

Chambers of Commerce

Technological Institutes
09 


$\begin{array}{ll}\text { Managerial Associations } & 16 \\ \text { Government Institutions } & 04 \\ \text { Others } & 06\end{array}$

It is interesting to note that at present, sixteen networks have participating technological institutes as partners.

\section{Funding of networks}

There were two types of grants. The first was an incentive to carry out feasibility studies and business plans. For those considered workable and profitable, a further grant was available for the establishment and development of a network.

\section{Advertising program}

Since the networking concept was new to area manufacturing firms, a four-point advertising campaign was initiated:

1. promotion by sectoral associations;

2. seminars in all major cities and larger municipalities;

3. production of brochures for distribution;

4. news releases to local and national news media.

\section{Summary of results of Impiva network program}

There was participation by 799 manufacturing and service firms. The four major areas of networking/alliancing included:

1. promotion, marketing and export development;

2. development/production of new products;

3. research and development;

4. joint purchasing agreements.

An analysis of established networks/alliances indicated that 62 per cent of the networks and 53 per cent of participating firms were concentrate in five industrial sectors including:

Advanced Tertiary

Textiles

Metal, Mechanical

Footwear
13 networks and 59 firms

10 networks and 124 firms

10 networks and 46 firms

10 networks and 136 firms 
Wood/Furniture $\quad 13$ networks and 63 firms.

The average number of firms in a network was four.

\section{U.S.A. networking programs}

Although some states and a number of municipal/private economic organizations have developed programs for the formation of strategic alliances between their local manufacturing/service sectors and global entities, there has not been a national program introduced dealing specifically with the development of alliancing.

According to a report provided to a Canadian Delegation in Chicago on October 17, 1991, by Lomond Inc., which was a joint venture between Morar Technologies, Inc., and Northfleet Management Group, Inc.:

"It is estimated that, in the U.S., alliances are growing at an annual rate of more than 20 per cent. During the ' 80 's U.S. firms formed more than 2,000 alliances with European companies alone."

However, in C. Richard Hatch's 1988 "Flexible Manufacturing Networks", the following statement appears:

"Fear of antitrust litigation and triple damage awards have effectively stifled cooperation in American industry. Firms, large and small, have been justifiably nervous about conversing, much less collaborating. The U.S. Congress is currently considering several bills, including a Small Business Networking Act that are intended to protect networks from legal interference and encourage manufacturing collaboration."

Perhaps this is one of the reasons why there are a number of outstanding successful network/strategic alliance programs operating at the state level rather than the national level. The following are some examples of state programs that have been successful.

\section{Oregon state}

In September, 1989, a fact-finding group of political and business representatives from Washington and Oregon undertook a two-week fact-finding trip to Europe sponsored by the German Marshall Fund.

Their first stop which was in the Emilia-Romagna region of Italy was a real eye-opener. With a 
population of four million people, there were 325,000 registered firms in their networking programs. In a report of the trip that appeared in the autumn Number 24, 1991 issue of the "Transatlantic Perspectives", State Senator W. Fawbush stated.

"The answer is a paradoxical combination of pragmatic co-operation and fierce competition."

The Italian CAMA, an association of wood products producers, jointly operates a warehouse, giving its members buying power and inventory management that none could achieve separately. The regional government also played a key supporting role in funding an array of industrial service centers.

Upon returning from the Oregon/Washington mission, the success of the CAMA operation in Italy was studied to see if a similar program could alleviate a serious crisis in Oregon's furniture/lumber sector. From 1989 to 1991, 10,000 jobs were lost in the wood sector with further losses anticipated.

In 1991, Senate Bill 364 was passed by an overwhelming majority. The "Wood Products Competitiveness Corporation" was established to direct the program. Two year funding of $\$ 2.25$ million was provided to develop a broad range of management, technical, safety, marketing, and other initiatives.

Another bill directed Oregon's Economic Development Department to begin developing industry associations, network broker-training programs and to establish a pilot network feasibility grant for other sectors of the economy.

A September, 1993 progress report, "Flexible Networks for Oregon Business" outlines some of the results after an eighteen month period:

1. thirteen key industries were included in the networking program;

2. over 250 firms participated in 31 flexible networks;

3. a training program was developed for the thirteen key industries and network brokers were trained in an eight day program.

The report emphasized the importance of:

Broker training: Oregon's flexible network brokers are an invaluable asset in helping companies organize networks. Brokers are crucial to the success of this initiative, and Oregon's Economic Development Department (OEDD) is devoted to this team of professionals representing thirteen key industries. 
Industry driven: All key industry program initiatives are industry-driven. Financial and staff assistance are provided on short-term basis to organize industry-wide strategic planning and help implement industry-led initiatives to improve competitiveness.

Flexible network definition: A flexible network is an alliance or partnership formed between three or more private companies to develop new markets, produce new products and increase profits. Networks enable companies to accomplish together what they are unable to do alone.

Challenge grants: Challenge grants were awarded to industry groups and associations to begin broad industry-wide discussion of flexible networks. Grants were used to help the groups explore the potential of networks to address shared competitive challenges and opportunities confronting key industries. (Six phase 1 grants were awarded up to June, 1992.)

\section{Network broker listings}

By establishing thirteen key industry sectors, Oregon was able to classify their network brokers according to the industrial sector they were best equipped to handle.

The thirteen key industrial sectors as established by OEDD included:

$\begin{aligned} \text { 1. } & \text { Aerospace } & \text { 2. } & \text { Agriculture } \\ \text { 3. } & \text { Biotechnology } & \text { 4. } & \text { Environmental } \\ \text { 5. } & \text { Fisheries } & \text { 6. } & \text { Film \& Video } \\ \text { 7. } & \text { Forest Products } & \text { 8. } & \text { High Technology } \\ \text { 9. } & \text { Metals } & \text { 10. } & \text { Plastics } \\ \text { 11. } & \text { Professional Services } & \text { 12. } & \text { Software } \\ \text { 13. } & \text { Tourism } & & \end{aligned}$

\section{Southeastern Ohio}

In 1985, the Appalachian Center for Economic Networks (ACEnet) was established covering a geographic area of eleven counties in rural Southeastern Ohio with a mandate to develop a variety of innovative strategies to assist the disenfranchised including worker cooperatives and small business incubators.

After considerable study of European models, it was decided that flexible manufacturing 
networks (FMN's) would be the most suited for the area. ACEnet is working on three levels to expedite the establishment of FMN's,

- an FMN pilot project (under a for-profit subsidiary);

- development of new products through a market network;

- a resource network involving ED groups, banks, funds.

Most FMN's established in the U.S.A. involve the same industry. ACEnet's approach to FMN's was slightly different in that it was concentrating on FMN's that are temporary production networks in which a small group of firms from different industries come together temporarily to produce a particular product which none of them could manufacture alone.

Another major difference in approach was the training program for future workers developed by ACEnet staff in conjunction with educational institutions, government agencies involved in training, community groups and most importantly, owners and workers of the small manufacturing firms who participated in the FMN's.

Because the whole concept was based on "niche" marketing, it was essential to make some basic changes in the training programs to meet the future needs of the FMN's. Changes involved:

1. programming sensitive to the increased presence of nontraditional workers;

2. bringing training entities together by forming new relationships made possible through joint activity;

3. linking training organizations with small firms;

4. building more flexibility into the guidelines for state and federal training programs.

ACEnet is certainly not typical of the network organizations already covered in this paper. Some of the important differences are based on the area's small manufacturing firms, an untrained disenfranchised labour base, lack of manufacturing sector "champions" and a rural atmosphere with limited sophisticated infrastructure.

Most importantly however is the success of the operation. After considerable research by the ACEnet staff, it was decided that with an ageing population, the passage of such federal bills as "Americans with Disabilities Act" and "Fair Housing Amendments" that related products represented the best potential.

A for-profit subsidiary, Accessible Designs - Adjustable Systems, Inc., (AD - AS) was 
established and designs were prepared for an adjustable kitchen by a consortium of designers, engineers and small manufacturers. There are four products being developed and a number of other complementary items on the drawing board. The program is a success and other FMN's are being planned to develop products to take advantage of "niche" markets.

The investigation of potential "niche" market products entails networking between end users, manufacturers, training cadre and sources of funding.

Success in one part of the world does not guarantee that the success can be replicated elsewhere in the world. A year of studying European examples suggests that identifying the underlying system dynamics, which can then be adapted to the particular culture and economy of a region, may yield better results than attempting to replicate highly visible structures (such as the associations which play a crucial role in Northern Italian FMN's).

\section{Pennsylvania}

Pennsylvania's "MATCH PENNYSLVANIA" program is an economic development program that has a section devoted to international connections. In 1991, a study of Canadian businesses by a Pennsylvania task force was undertaken utilizing the "DELPHI" system (a system that involves surveying firms with common characteristics) with the major emphasis of the survey being Canadian firms presently participating in the U.S.A. market and others with future plans to access the U.S.A. market.

In 1992, a further study was conducted with the following results:

- 4,569 survey forms mailed;

- 329 replies (7.2 per cent);

- 72 per cent of respondents were at the time exporting to the U.S.A. and 60 per cent had representation in the U.S.A.;

- 34 per cent were interested in forming joint ventures, strategic alliances.

Concurrently, Pennsylvania firms were being contacted regarding their participation in the Canadian marketplace. From the internal program, 1,000 Pennsylvania firms completed a survey form similar to the one used in Canada. This computer data base allowed any outside request for a possible Pennsylvania strategic alliance partner to be identified immediately. The data sheets sent to the outside source use a coding system for confidentiality purposes and company names are not provided initially.

Therefore, the State department acts as the business broker between firms but not necessarily in the full context of establishing networks or strategic alliances. 


\section{Other state programs}

There are other states involved in various forms of strategic alliancing. Washington State has a number of wood sector firms in a network; Michigan has its Market Observatories program and the Michigan Modernization Service; on the Minnesota/Dakota border, forty firms are allied in the Tri-State Manufacturers Association; Florida, Massachusetts, Maine, Mississippi, West Virginia North Carolina and Montana are also reported to have active networking programs.

\section{Findings of professor C. R. Hatch}

Professor C. Richard Hatch of the Center for Manufacturing Systems at the New Jersey Institute of Technology has been a leading proponent of the network concept and the following points were published in "Transatlantic Perspectives", (Number 22; Winter 1991).

"As firm size goes down, the need for assistance goes up; the traditional limitations of small firms - restricted access to capital, little or no R \& D capability, lack of management depth and marketing savvy - are well known. The magnitude of the problem, the limited time remaining to reach competitive levels, and the shortage of public resources are driving home the need for new approaches."

In the article, Mr. Hatch suggests five working principles for a Network Strategy:

The profit incentive principle: Many European regions drive for modernization has been achieved by finding profitable business opportunities (niche markets);

The efficiency principle: With public funds drying up, it will be impossible for governments at all levels to assist individual firms but they can provide quality services to groups of firms (Networks, Alliances, etc.);

The principle of maximum feasible participation: To get industry involved in continuous modernization, put it in charge of the process. This shift from supply-side to demand side- has revolutionized Italian industry;

The principle of sustainability: If services are offered free by government agencies and resources are limited, most programs remain small. However, by increasing service fees commensurate with new gains in profits, services provided are industry driven and become self-sustaining;

The principle of cooperation: In North America, firms are expected to cope with global manufacturing changes by themselves. In some countries of Europe, they 
are fostering a different kind of industrial system, one in which cooperation forms the basis for competitive success.

In the same article, Mr. Hatch provides five steps that are needed to develop and expand networks and strategic alliances. Utilization of the five principles espoused by Professor Hatch and the five steps for the proper management of networks will be used as a basis for comparison with the efforts of Canadian agencies in networking/alliancing.

1. Recruit brokers: Whether they are from government agencies, local economic development organizations, trade associations, community colleges, university extension programs or trained as network brokers, they are essential for a continuing and growing network program.

2. Get them talking: Establish regular communications among and between firms, labour unions, marketing specialists, product designers, university laboratories, equipment manufacturers, AND SUPPLIERS!

3. Deploy skills, not firms: Firms are packets of skill and equipment that can be deployed in changing network combinations in response to market signals.

4. Spot common needs: By identifying critical problems for sector competitiveness through constant contact, common needs can become the basis for collective solutions.

5. Work toward hubs: Turn obstacles to growth into specialized services - services that no small firm could possibly afford except through network participation. These crucial collective services will be the hubs around which network cooperation coalesces.

As stated in the introduction, "Various countries throughout the world have developed strategic alliance programs based on their own national needs of the manufacturing and service sectors."

Before examining various levels of networking and strategic alliance programs presently operating in Canada, it was important to consider similar programs in operation in the global marketplace and the results achieved by them. They are major competitors to Canada's manufacturing and service sectors and as such, to remain competitive, national programs have to equal or better what is presently available outside Canada.

\section{Canada at the crossroads the reality of a new competitive environment}

In 1991, the Honourable Michael Wilson, P.C., M.P., Minister of Industry, Science and Technology, Canada, commissioned Michael E. Porter, Professor of Business Administration, Harvard Business School and the Monitor Company Canada Limited to produce a report on the 
present economic health of Canada and corrective measures required to bring Canada to the level of international competition standards as made possible through the formation of strategic alliances and networks.

The final report, consisting of 468 pages, is fascinating reading. Some of the findings are highly critical of how Canadian industry is reacting to globalization. On page three, Mr. Porter writes:

"Canadian industry is currently undergoing a rapid structural change. Signs are already accumulating that Canadian industry is encountering difficulties as it confronts this changed and more competitive environment. If the current trajectory continues, the standard of living of Canadians seems destined to fall behind."

Mr. Porter's famed "value-added chain" Figure 2: Model for development of new products; has been used for many years as a basis for successful programs of networking involving manufacturing firms and service organizations. However, a more sophisticated model was required when national policies were added as an integral part of the equation. A new model aptly called the "Diamond" was proposed as a working program for Canadian industry.

In explaining his newly enlarged "Diamond" model Mr. Porter states:

"Sustained competitive advantage results from rapid improvement and innovation, not static advantages. Here innovation is defined in the broadest sense of the word, to encompass not only technology but the full spectrum of methods of competing. In order to ensure success, innovation must anticipate international, not just domestic needs. Moreover, the creation of competitive advantage is not a one-time occurrence. Sustaining advantage requires that its sources be relentlessly broadened and upgraded to more sophisticated types."

Mr. Porter further refines the "diamond" by adding in "factor" conditions including:

Basic factors are those inherited by a nation or created through moderate investment, including natural resources, climate, and unskilled or semi-skilled labour.

Advanced factors are those developed through sustained and sophisticated investment in both human and physical capital, such as modern digital data communications infrastructure or world-class university research institutions.

General production factors can be employed in a wide range of industries such as 
a highway system or a cadre of college graduates.

Specialized production factors are those that are relevant to one or a limited range of industries, such as an optics research institute or a port specialized in handling newsprint.

When the above factors are taken into consideration and applied to the principles shown inside the "diamond" model, two wildcard factors outside the "diamond" but bearing on all other segments, government and chance, provide a very powerful model for use by the Canadian manufacturing and service sectors in their search for global competitiveness through the use of networking and alliancing.

The report notes a word of caution.

"Each of the four determinants of competitiveness - factor conditions, demand conditions, related and supporting industries, and firm strategy, structure and rivalry--influences the capacity of a nation's industry to innovate and upgrade. Together they constitute a dynamic system that is more important than its parts. Over time, the determinants tend to be mutually reinforcing or mutually undermining." (Porter, 1991; p. 63)

\section{Assessing the Canadian diamond}

Mr. Porter puts the onus on individual firms for assessing the diamond as it pertains to their own operations.

"Firms need to understand clearly their competitive position by product area as well as how their Canadian home base creates advantages and disadvantages. This will require that they assess themselves in a different way from the past. The important reference points will be the most formidable international competitors. These firms, as well as the national diamonds in which they are based, provide the benchmarks against which Canadian conditions must be assessed."

If a manufacturing sector, either as a whole or individual firms within the sector do not have a dedicated responsibility of action in the process of networking/alliancing, nothing will be done. Considering the fact that Mr. Porter's study "Canada at the Crossroads " was presented eight years ago to a government party who is no longer in power, does not preclude the value of its messages to improve Canada's manufacturing sectors. 
"Canadian governments have had a strong tendency to intervene directly in competition rather than stimulate upgrading by industry itself." (Porter, 1991: p. 345)

The balance of the paper analyses Canada's history in the field of networking/alliancing and some of the results will be measured against the standards of Porter's book. When one considers that "Canada at the Crossroads" was a truly independent research project encompassing research by leading practitioners and academics from Canada and the United States of America, the result was a road map to success in the global marketplace and many of the revolutionary ideas put forth in the 1991 study have withstood the test of time during the last eight tumultuous years.

\section{Barriers for the Canadian economy}

Porter's presentation includes in-depth analysis of the following Canadian industries: News Print, Whiskey, Central Office Switch Systems and Geophysical Contracting. As he states:

"There is no one diamond that describes all industries in Canada - each industry has a unique diamond, the strength of which is driven by features specific to that industry. Therefore, the barriers we have identified vary in their importance to and impact on specific industries. Virtually all industries we have examined are affected by at least some of these barriers." (Porter, 1991; p. 352)

An important point made by Porter relates to Canada's labour force featured in Figure 4. He points out that:

"Canada's workforce is not well equipped for upgrading and change. The basic skill levels of many citizens are inadequate, in spite of high per capita spending on education. Shortages exist or are looming in skill and technology related occupations, a vestige of the old order. Specialized skill development is lagging due to poor vocational apprenticeship training and weak links between educational institutions and industry."

\section{Network incentives federal government}

Whether because of the presentation of Michael E. Porter's "Canada at the Crossroads" report in 1991 or the proliferation of business magazine articles covering flexible manufacturing networks, virtual corporations, networking, Industry Canada started researching successful networking programs in all parts of the world.

At around the same time, the Canadian Manufacturers Association (CMA) was studying the 
United Kingdom program and the highly publicized Danish model. A small number of CMA officials visited the U.K. and took the training course for network brokers. At various public meetings, CMA officials suggested that their organization become the agency for the training of network brokers and the major organization for assisting in the establishment of a Canadian networking program.

The non-profit organization, Regional Technology Strategies and CMA formed the Canadian Network Foundation (Can-Net).

Concurrently, the Economic Developers Association of Canada and the Canadian Chamber of Commerce plus many other interested agencies (Figure 5) were meeting regularly to establish a networking program for Canada. Mr. Philippe Roy, CMC, presented a paper "Vision for a Nation: Business Networks", to the Canadian Chamber of Commerce and the Canadian Business Networks Coalition (CBNC) on January 25th, 1995. It was well received and many of Mr. Roy's recommendations were incorporated in the constitution of the newly formed CBNC.

\section{CBNC Mandate}

1. Time frame: The CBNC has a time frame of two years. At present (1997), there is an application to have the time frame extended. (Please note - No extension of the mandate was granted.)

2. Main thrust: The establishment of 30 viable strategic alliances among small and medium-sized businesses in every region of the country.

3. Other programs: The funding of local roundtables designed to educate and establish business networks.

4. Funding: Partial financial support from Industry Canada with remaining funding to come from the private sector (Total $\$ 4.5$ Million)

\section{Establishment of broker training: A National Business Network}

Demonstration Project was set up under the auspices of Confederation College who arranged eight training sessions for network brokers across Canada with the participants earning the designation Business Network Advisor (BNA). 


\section{Training programs}

\section{The brokers}

As part of its operating mandate, the CBNC was responsible for the establishment of a broker or mentor training program. The Canadian program was handled by Confederation College. The fee for the 5-day course was $\$ 1,000$. Each registrant received a large binder of pre-reading material on alliancing and networking.

The Table of Contents was divided into twelve modules plus guest lecturers on specific subject matter. The modules included:

$\begin{array}{ll}\text { Module } 1 & \text { Introduction } \\ \text { Module 2 } & \text { Selling Business Network Cooperation } \\ \text { Module } 3 & \text { Business Network Theory } \\ \text { Module } 4 & \text { Critical Input Factors } \\ \text { Module 5 } & \text { Seeking Partners } \\ \text { Module 6 } & \text { Initial Business Network Design } \\ \text { Module 7 } & \text { Drawing Up Business Plans and Agreements } \\ \text { Module 8 } & \text { Network Management and Human Dynamics } \\ \text { Module 9 } & \text { The Business of Network Advising } \\ \text { Module 10 } & \text { Introduction to Financial Management } \\ \text { Module 11 } & \text { Information Technology } \\ \text { Module 12 } & \text { Legal Considerations }\end{array}$

On the surface, it appears to be an excellent training program but there is room for improvement. The comments that follow are based on my participation in the course, being a guest lecturer and having thirty-nine years of active Economic Development and Consulting experience in alliancing and networking.

Screening of registrants

Without some background in economics, law, accounting, economic development or senior management, a registrant would be a hindrance to the rest of the class. The Business Network Advisor (BNA) designation carries a heavy load of responsibility. In their role of advising how a network or strategic alliance should be formed and operated, an unqualified person with a BNA designation could do irreparable damage to the firms involved. 
Therefore, a screening matrix should be developed listing attributes that are essential for a BNA designation with value points for each heading. A second group of headings should be developed to include desireable past business history, plus points for academic levels, etc. Financial knowledge, as an example would be a requisite. However, for those subjects considered essential, a time frame should be granted for the required training to be undertaken at an accredited educational institute.

Only those candidates receiving the required number of points would be provided the opportunity of participating in a BNA training program.

\section{The scout}

In the Danish model, the scout program involved two, three-day sessions while the Spanish Impiva network was four, two-day sessions. In the Impiva case, most of the scouts whose job was the searching for possible network or alliance opportunities were professionals consisting primarily of economists.

In Canada, a "scout" training program could include Chamber of Commerce Managers, Economic Development Professionals, Consultants, Association Managers, Corporate personnel responsible for locating strategic alliance opportunities.

This training would assist in defusing possible turf war problems and could provide leads on strategic alliance opportunities for brokers.

The last point would be the sector classifications similar to the previously noted Oregon program, that the Broker could handle in a professional manner. Industry Canada lists 22 sectors in their latest "Canada's International Business Strategy" and this could be the basis for the listing.

\section{The SME manager}

This training program could be the most important. An old adage states "People Resist Change" and this is particularly true when it comes to entrepreneurs being introduced to a strategic alliancing opportunity for the first time.

Industry Canada presently has a course developed for introducing senior executives to strategic alliancing. DFAIT also produces a small brochure "Building Successful Strategic Alliances" that could be used as a basis for an excellent executive training program.

Most small SME's would not attend such a course if they had to pay the full attendance cost. 
However, there are a number of ways that the program could be offered that would make it acceptable to smaller SME executives.

1. Provide a subsidy to those attending the course but only if they were in attendance at all classes.

2. Approach sector associations for financial support for members taking the course.

3. Underwrite a training organization to present the course across Canada thereby lowering the cost for attendees.

\section{Funding - federal level}

Funding of any type for the establishment of networks/alliances must be on a partnership basis. It should involve three levels, the federal government, the provincial governments and the SME involved.

To date, the $\$ 2.5$ million provided to the CBNC for the establishment of 30 networks across Canada has been repaid many times by the new developments that have been created. As previously mentioned, any Canadian development in the network/alliance fields must be equal or superior to similar programs in operation around the world. However, funding programs should assist with the heavy front-end costs experienced in researching and establishing a network/alliance. The funding must be seen as supportive not as subsidization.

Perhaps the funding could follow the present program of the CBNC. However, rather than working on networks which are important but do not have the same future growth potentials as SME flexible manufacturing networks, major emphasis could be placed on the latter.

\section{Other potential funding by federal agencies}

\section{Export development corporation (EDC)}

Exports are the life-blood of Canada. At present, we as a nation are not using our natural resources to best advantage. Michael Porter (1991) states,

\footnotetext{
"Resource-based exports account for 45.8 per cent of Canada's total exports. Canada has by far the highest share of country exports in unprocessed and semi-processed natural resources of any of the nine nations we studied. By contrast, Sweden, another nation with substantial natural resources, exports resource-based products largely in the form of processed goods."
} 
An export-based SME FMN could receive support from the Export Development Corporation, especially if they were adding value to a natural resource.

\section{Tourism Canada}

Tourism has the best record of creating new jobs but even with our wonderful tourism opportunities, Canada has a deficit in the in-bound/out-bound tourist dollars.

Tourism Canada would be the natural vehicle for developing a funding program for the establishment of tourism oriented networks/alliances. Package programs are essential to meet global competition and front-end load assistance is urgently required by our many tourism operators across the country in establishing networks between participating bodies involved in a total tourism package.

\section{Canada versus the world: Where do we stand what can we do about it}

Canada is an immense country sparsely populated (based on population per square kilometer) with a bounteous gift of natural resources and bordering one of the largest markets in the world, the United States of America. Most of Canada's population is concentrated within 100 kilometers of that long border which stretches from coast to coast.

Some centres of population such as Southern Ontario, Montreal, Vancouver, Winnipeg, Calgary, Halifax and Edmonton are as dense as those in many European countries. Denmark with less population than the Greater Toronto Area and smaller in area than any of the Great Lakes invested $\$ 30$ million in their flexible manufacturing network program.

Canada's program that borrowed some of its operating procedures from the Danish model invested \$2.5 million spread right across Canada in establishing the Canadian Business Networks Coalition, CBNC (Figure 5). This highlights one of our major problems. A flexible manufacturing network program could be highly successful in some of the business centres mentioned above but for FMN's to work, it requires a density of population and SME's that are only found in major population and manufacturing centres.

In other parts of Canada like the Prairie Provinces, another format, clusters, are proving highly successful in the natural resource sectors of food, natural gas and oil. New Brunswick has developed some successful clusters via advanced fibre-optics communications systems and incentives. The pacific salmon trade has developed a network involving thousands of fishermen, interconnecting companies and trade associations.

So even with the minimal amount of investment in the CBNC, it has been leveraged by various 
economic groups in Canada in a forceful and progressive manner.

\section{Some provincial programs: Investment matching service of Alberta (IMSA)}

Alberta has an active program promoting strategic alliancing between Alberta firms and global partners. The program is named "Investment Matching Service of Alberta" (IMSA).

The IMSA produces two catalogues a year listing manufacturing and service firms looking for strategic partners, in some cases equity financing, sales opportunities, licensing arrangements, training programs and technology transfer proposals.

Whereas most of the catalogues are multi-sector oriented, the IMSA has produced catalogues pertaining to single sector industries (Alberta's Food Processing Industry, October, 1995)

\section{Business industry development - B.C.}

In 1988, British Columbia entered the Strategic Alliance field with the establishment of the "Business Industry Development - B.C." (B.I.D.-B.C.) B.I.D.-B.C. had a mandate of two years and operated under the following terms of reference:

1. Cross sectoral;

2. Focus - Government procurement - Ottawa;

3. To increase British Columbia participation in federal government contracts;

4. Act as facilitator or broker;

5. Private sector managed.

In two years, seventeen flexible business networks involving 591 companies, all in associations, were established with a goal of launching two new networks yearly. The network representing the pacific salmon trade was extensive involving 4,000 fishermen, 25 companies and 29 associations.

At the end of a slide presentation on the operation of B.I.D.-B.C., a list of essential factors and lessons learned were provided. Many of the essential factors and learned lessons are repeated in numerous other papers under study.

Essential Factors:

- Total company commitment;

- Knowledgeable brokers or facilitators;

- Proper company structures; 
- Adequate funding by all parties.

Lessons Learned:

- Need to focus export activities;

- Foster cooperation and teamwork;

- Build TRUST;

- Pool resources and talent;

- Enhance success ratio.

\section{Province of Quebec}

The Province of Quebec is strongly involved in strategic alliancing using its foreign offices to develop overseas leads.

\section{Other Canadian alliance programs}

There are other provincial, regional and community network programs in operation across Canada. For instance, the City of Vaughan, Ontario received funding from York Region and Human Resource Development Canada for the establishment of a strategic alliance program similar to Durham Region's strategic alliance plan. Also, Brampton, Ontario, under the leadership of the Economic Development Department has an active alliance program in operation.

Durham Region has one of the most comprehensive strategic alliance programs at a regional level. The following is a description of their program.

\section{Durham region's strategic alliance program}

The Regional Municipality of Durham is located immediately east of Metropolitan Toronto and is part of the Greater Toronto Area (GTA). With a population base of 458,000 residents in 8 communities, it has a strong industrial base covering a number of sectors including auto parts which supply a major General Motors manufacturing and assembly plant.

In 1989 after a business visit to the Hannover Fair, Germany plus a tour of Germany and Austria, regional representatives in visiting to Canadian Embassies and consulates came to the realization that the excellent government data bases of Canadian manufacturing firms (World Information Network for Exporters WIN) provided essential information on firms interested and capable of exporting. However, there was no mention of firms interested in partnering and willing to provide the three essentials necessary for strategic alliancing: finances, dedicated personnel and 
time.

After two years of research, Durham Region launched its "Joint Venture Opportunities in Durham Region" program which involved the distribution of a binder with pertinent strategic alliance information on 100 Durham firms, to all Canadian embassies and consulates world-wide plus many other foreign government commercial offices.

Many potential strategic alliance opportunities received from overseas sources were provided to Durham Region manufacturing firms participating in the program. It soon became evident that an owner of a Durham manufacturing operation could complete a multi-million dollar tender with no difficulty because he/she knew the terms of reference. However, the same party would either ignore or turn down a perfect strategic alliance opportunity due to lack of knowledge of the process.

Therefore, an educational program was instituted and a number of seminars on strategic alliancing were presented to the chief executives and business leaders of Durham Region. Terminology became a major stumbling block (networks versus strategic alliances, etc.) and in some cases, potential strategic alliances from off-shore failed due to cultural differences and a lack of knowledge of what was expected from the involved parties.

Was the program a success? Yes, in many ways different from that expected. The profile of Durham Region was forever changed from being a part of the GTA to being a major Canadian contender in the global marketplace. Its manufacturers entered the global market and many, on their own, undertook the establishment of strategic alliances.

\section{Durham region's business alliance network}

After a two day Strategic Alliance training session based on a course developed for Industry Canada, a number of manufacturers spearheaded by Carl Wintermeyer, a local manufacturing executive and long-time proponent of strategic alliancing with the support of the Economic Development Department of Durham Region developed a new program, the "Business Alliance Network" (BAN).

This program which involved Durham firms networking and alliancing with other Durham firms has evolved into a "cluster" which is constantly changing to keep up with the rapidly changing global economy.

Some of the lessons learned in operating this program can be of value to other regions or municipalities across Canada. 
1. Champions: To be successful, the program needs champions, preferably from the manufacturing sector.

In a Department of Foreign Affairs and International Trade (DFAIT) brochure, authors Micheal J. Kelly, Ph.D., and Jean-Louis Schaan, Ph.D., "The Management and Implementation of Strategic Alliances in the Canadian High Technology Industry" state:

"Forty-six per cent of respondents cited alliance champions as being extremely important to alliance implementation and management. Another 34 per cent rated them important. Executives of larger firms were likely to rate this factor as being of greater importance than those of medium-size or small firms."

2. Leadership: It is essential that leadership comes from the industrial/manufacturing/service sectors even though local EDO's may serve in an advisory capacity.

T. Peridis in his "Strategic Alliances: In the Quest for Global Competitiveness, 1996 states:

"In many joint ventures, a lead partner is designated and is responsible for all operating decisions, with a balanced board of directors being the overseer."

3. Local government services: Local government support is essential. With many economic development departments understaffed and in many cases underfunded, the infrastructure required to form strategic alliances should be combined with services already in place to save personnel time and money.

Communications can be in the form of a newsletter, by e-mail, fax or regular group meetings. New government programs applicable to strategic alliancing can be brought to the attention of the alliance/network groups. Niche market opportunities that appear in publications can also become a low-cost high-support function.

4. Training of key personnel in alliances: It has been essential to present training programs in strategic alliancing. It is a new procedure for many managers and without training and understanding, most proposals will be rejected.

David E. Raphael (1993) Case Study: Corning Incorporated

"Corning relies on the learning process to meet objectives in its many alliances. According to CEO James R. Houghton, Corning has managed more than 40 
alliances in the past 60 years.

Learning is a critical success factor in meeting Corning's goals as well as the goals of the alliance. Corning employees and alliance managers receive 100 hours of training each year. Training extends to senior management, including Chairman Houghton.”

C. Richard Hatch (1988), Flexible Manufacturing Networks:

"Successful applicants should be trained, along with the public and private sector representatives whose support they will need, to understand the network process."

5. Funding - At Durham, the Oshawa office of Human Resource Development Canada provided funding based on the realization that managers with strategic alliance training were more likely to retain present workers and hire new staff based on growth generated by strategic alliances.

Partnering with other private and public sources including community colleges can provide necessary funding for the establishment of a strategic alliance program.

In Working Paper Number 13, 1996, Sunder Magun, provides four major reasons for forming a strategic alliance:

"First, it increases the effectiveness of the participating firms' competitive business strategies;

Second, the members of the alliance remain independent after negotiating the collaborative arrangement;

Third, the members of the alliance share control over the performance of its functions and tasks, and also share in the benefits;

Fourth, the partners make a strategic contribution to the alliance, such as knowledge, technology, critical skills, equity-capital or products."

\section{Eight years after "Canada at the crossroads"}

It has been eight years since Michael E. Porter and the Monitor Company provided the Canadian Government with an innovative road map for economic recovery through strategic alliances, networking, advanced technology clusters and benchmarks to accurately measure whether, as a 
nation, we are going forward or backward.

We were given the tools. Have we used them?

\section{Conclusion}

If "Canada at the Crossroads" was the examination paper and Canada was the student, it would be difficult to justify a passing mark.

This may seem harsh but it is based on either a complete lack of effort or a minimal attempt by Canada in many key areas of strategic alliancing that have proven so essential in other countries that have developed successful programs. However, as previously noted, Canada is an immense country with great variances in population densities, types of terrain, diffusion of natural resources and many levels of governmental jurisdictions that would make a go-alone "national" policy not only impossible but undesirable.

Therefore, if Canada is going to excel in the area of strategic alliancing, it must be through the formation of strategic alliances between the national, provincial, regional, municipal governments plus close cooperation among industrial associations, specific industrial sectors, universities and the many service sectors that add so much to the country's well being and wealth.

The following are some corrective measures that could assist Canada's strategic alliance program.

\section{Broker accreditation}

1. The basic "Business Network Advisor (BNA)" accreditation does not have upgrade requirements as a requisite for continuing the usage of the designation. Industry Canada should investigate upgrade requirements as those apply to other designations such as $\mathrm{EcD}$, CED and establish standards for the BNA designation.

2. Analyse present educational and training standards such as those established by the Institute of Certified Management Consultants of Ontario to see if their standards are sufficient in scope to have them approved as accredited BNA's or whether their standards could be utilized as a base for BNA certification.

3. Funding for essential training of Brokers should be undertaken by Industry Canada in partnership with similar provincial bodies and/or business associations. 


\section{SME executive training}

Many global enterprises have dedicated personnel responsible for locating profitable strategic alliance opportunities. In Canada, executives of SME's with a working knowledge of alliancing are few in number.

Whereas Industry Canada already has a basic training course for their senior staff members, this same course, with minor modifications, could be made available to SME leaders with some type of funding provided to training organizations capable of handling such a course.

In October, 1995, Robert Denomme \& Assoc. produced "A Framework for Management Skills and Competency Standards and Guidelines for Small Business Owner/Operator/Entrepreneur for the "Sector Councils Steering Committee.

The study uses elements of the "Standard for Small Business Owner" developed by the Alberta Tourism Education Council. The format of the Alberta Tourism Education Council could be a basis for sector specialization training in strategic alliancing.

\section{Academic training}

It will be essential for our future industrialists to be knowledgeable in alliancing procedures if Canada is to keep abreast of international opportunities in this field.

Once Industry Canada undertakes the responsibility of creating a national policy of alliancing in conjunction with provincial economic development departments and other organizations involved in this field such as EDAC, universities should be consulted and a course developed as part of a business degree and BNA accreditation.

Training based on a national policy that is acceptable to the provinces and other jurisdictions would place Canada in the forefront of the strategic alliance field.

The quotation by Mr. Silverman to the University of Waterloo program, Aylmer, Quebec, on February 19th, 1997 says it all.

"Canada cannot take for granted that it will converge with other countries in technological capabilities or innovation performance. Recent research on economic growth has revealed that, contrary to what would have been expected from traditional economic theory, there is no common path followed by countries. Rather, studies find persistent differences in long-term growth performance and patterns of international technology specialization of groups of countries. 
This is a rather spooky conclusion, because it means that not only do we have to maintain a competitive advantage at the level of each firm, we also have to continually engineer new comparative advantages as a nation."

\section{Author's biography}

Joseph Montgomery was the Economic Development Director, City of Niagara Falls and the Niagara Region for 27 years, retiring in 1987 to operate his own consulting firm, Jos. Montgomery Consultants, Niagara Falls. He has established a number of strategic alliances over the past decade about which he has written in this volume. More recently his consulting activities have concentrated on studies involving tourism and recreational sport fishing. He holds the President's Award from both the Economic Development Council of Ontario (EDCO) and the Economic Developers Association of Canada (EDAC). Joe is an Honorary Life Member of the American Economic Development Council (AEDC), Economic Developers Council of Ontario (EDCO) and the Economic Developers Association of Canada (EDAC).

\section{Bibliography}

Appalachian Center for Economic Networks, Creating Flexible Manufacturing Networks, ACEnet, 1991.

Appalachian Center for Economic Networks, A Market Driven Approach to Flexible Networks, ACEnet, 1993.

Appalachian Center for Economic Networks, A New Approach to Job Trainin, ACEnet, 1993.

Blais P., "The Competitive Advantage of City-Regions”, Policy Options, 1994, pp. 15-19.

British Columbia Trade Development Corporation, Flexible Business Networks (Strategic Alliances), Province of British Columbia, 1988.

Canada Foundation for Innovation, Building the Future for Canadians. Budget, Catalogue Number Fll-23/1997-7E, 1997.

Canada - Germany, Links for Business Growth, DFAIT, 1996.

Celeste R.F. Winter, Strategic Alliances for Innovation, American Economic Development Council, 1996. 
City of Vaughan, Strategic/Business Alliances Directory, 1997.

Denomme, Robert \& Assoc., A Framework for Management Skills and Competency Standards and Guidelines for Small Business Owner/Operator/Entrepreneur, 995.

Durham Region Economic Development Department, The Driving Force Behind Economic Growth of the Regions, Durham Region, 1997.

Fawbush W. and J. Cortright, "European Economic Development Ideas Take Root in Oregon”, Transatlantic Perspectives, Autumn, 1991.

Fitchett G.A. and J.D. Alton, "Strategic Alliances and Joint Ventures", 13E the Canadian Business Financing Handbook, 1991.

Government of Canada, Canada's International Business Strategy, Minister of Supply and Services, 1996.

Grantham J., Danish Network Program, Canadian Embassy, Copenhagen, 1992.

Hall L., J. Ducharme and J. Sweeting, Economic Development Strategy for the City of Niagara Falls, KPMG, 1996.

Hatch C.R., Flexible Maufacturing Networks, Corporation for Enterprise Development, 1988.

Hatch C.R., “The Power of Manufacturing Networks". Transatlantic Perspectives, Winter, 1991. Industry Canada, Building Successful Strategic Alliances, DFAIT, 1998.

Institute of Certified Management Consultants of Ontario, General Information on ICMCO Exams \& Seminars, 1997

Jones S., Flexible Business Network, German Marshall Fund of the United States, 1992.

Kelly M.J. and J.L. Schaam, The Management and Implementation of Strategic Alliances in the Canadina High Technology Industry, DFAIT, 1996.

KPMG. Building Technical Bridges Cluster Based Technology, Volume 1, KPMG, 1996.

Lever A.N., "Strengths of an Alliance", The Economic and Technology Development Journal of Canada, 1997. 
Magun S., The Development of Strategic Alliances in Canadian Industries: A Micro Analysis, Industry Canada, 1996.

Myhrvold T., Networks - An Opportunity also for Canadian Companies. Norwegian Industrial and Regional Development Fund, 1993.

Olive P. and J. Montgomery, Strategic Alliances, Joint Venture Program of the Durham Region, Ontario, American Economic Development Council, Winter, 1993.

Oregon Helping Oregon, Flexible Networks for Oregon Business, State of Oregon, 1993.

Peinado S.H., Cooperation Among Industries in the Valencian Community. Impiva, Spain, 1993.

Pennsylvania, State of, Data on Strategic Alliances and Joint Ventures (Canadian Delphi Research Study), State of Pennsylvania, 1995

Peridis T., Strategic Alliances: In the Quest for Global Competitiveness, 1996.

Porter M.E., Canada at the Crossroads, The Monitor Company, 1991

Raphael D.E., Spring, Managing and Growing Strategic Alliances, Marcar Management Institute, 1993.

Rosenfeld S., Jump-Starting Networks, Firm Connections, July/August 1993.

Roy P., Vision for a Nation - Business Networks, Privately Published 1995.

Roy P., Business Networks and Network Hubs, Industry, Science and Technology, Canada., 1992.

Sainsbury K., Networks: Implications for Local and Regional Development, Thesis, 1997.

Silverman O., Technology and Industrial Competitiveness: The Policy Responds, Industry Canada, 1997.

Suskind B., "Making Contact: The Skill of Networking", The Economic and Technology Development Journal of Canada, 1997. 